\title{
Entre Chapultepec e o Rio de Janeiro: o "problema argentino", o Livro Azul e suas repercussões
}

\author{
Sydenham Lourenço Neto ${ }^{1}$
}

\begin{abstract}
RESUMO: O objetivo deste texto é investigar as razões que levaram o Departamento de Estado dos EUA a publicar em 1946 o Livro Azul sobre a Argentina, as repercussões na imprensa brasileira e estrangeira dessa publicação e as implicações para a criação do sistema interamericano e especialmente para as negociações que trataram da realização da Conferência do Rio de Janeiro em 1947. Nossa hipótese é que a reação do Brasil e de outras Repúblicas do continente, minimizando o conteúdo das denúncias apresentadas no Livro Azul, constituíram uma derrota para os EUA e delimitam, no caso brasileiro, aquilo que os especialistas têm chamado de "alinhamento sem recompensas" com os EUA e "diplomacia da obstrução" com relação à Argentina.
\end{abstract}

Palavras-chave: Sistema Interamericano, Livro Azul, Conferência de Chapultepec, Conferência do Rio de Janeiro, Alinhamento Brasil-EUA.

\section{Between Chapultepec and Rio de Janeiro: The "Argentine problem", the Blue Book and its repercussions}

ABSTRACT: This paper investigates the publication of the Blue Book on Argentina in 1946 by the US Department of State, the reasons behind this publication, its impact on the Brazilian and world press, and finally its implications for the creation of an interAmerican system and for the negotiations around the realization of the Rio de Janeiro Conference in 1947. We argue that Brazil's reaction, as well as the reaction of other Latin American countries, which dismissed the gravity of the Blue Book's main denounces, was a defeat for the USA and shaped, in the Brazilian case, what scholars have called a "no rewards alignment" with the US and a "diplomacy of obstruction" regarding Argentina.

Keywords: Inter-American System, Blue Book of Argentine, Chapultepec Conference, Conference of Rio de Janeiro, Brazil-US alliance.

Artigo recebido em: 01/09/2016

Artigo aceito para publicação em: 19/03/2017

\footnotetext{
${ }^{1}$ Doutor em Ciência Política pelo IUPERJ, professor associado da UERJ, membro do corpo docente do PPGHS-UERJ. O artigo faz parte da pesquisa "Relações Internacionais burocracia: o Itamaraty - da Segunda Guerra ao início da Guerra Fria". Endereço profissional: R. Dr. Francisco Portela, 1470 Patronato, São Gonçalo - RJ, 24435-005, slneto@hotmail.com
}

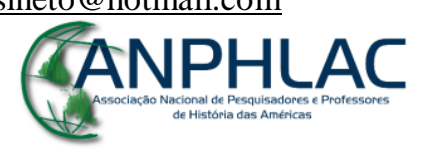




\section{Introdução}

Já em 1944, enquanto combates ainda aconteciam na Europa e no Pacífico, EUA, Inglaterra e URSS se empenhavam em construir as bases diplomáticas para o mundo do pós-guerra. Nas Conferências de Dumbarton Oaks, os três grandes, posteriormente adicionando a representação oficial da China, buscaram lançar as bases da Organização das Nações Unidas (ONU). Neste mesmo momento, os países da América Latina pressionavam os Estados Unidos para participar do desenho da ordem mundial do pós-guerra.

Os EUA, nesse momento, estavam mais preocupados com a construção da Organização das Nações Unidas (ONU) e com a configuração da nova ordem econômica mundial, através do Tratado de Bretton Woods. Porém, não podia desprezar completamente as demandas dos países latino-americanos, que, em sua maioria, foram fiéis aliados durante a Segunda Guerra. Existia entre as nações menos desenvolvidas do Continente a preocupação com um possível abandono por parte da "Grande Nação do Norte", uma vez que a vitória dos aliados se consolidasse.

A determinação dos países latino-americanos, incluindo aliados fundamentais durante a Segunda Guerra, como o Brasil e o México, parece ter sensibilizado o governo dos EUA e, no início de 1945, começou a montagem do Sistema Interamericano que levou a criação da Organização dos Países Americanos (OEA). As Conferências de Chapultepec (1945), Rio de Janeiro (1947) e Bogotá (1948) ratificaram os acordos que fundamentaram o Sistema Interamericano. Entretanto, especialmente entre a primeira e a segunda Conferência, o "problema argentino" por pouco não inviabilizou a aliança continental.

Por "problema argentino", caracterizamos a resistência dos EUA em aceitar a participação da Argentina governada pelos militares que assumiram o poder em 1943 e que resistiram a todas as pressões dos EUA para declarar guerra ao Eixo até a véspera da tomada de Berlim pelas tropas aliadas. Como consequência do Golpe Militar de 1943, subiu ao poder na Argentina o general Pedro Ramírez e posteriormente, no início de 1944, o general Edelmiro Farrell que tinha como ministro da guerra o coronel Juan Domingo Perón. (RAPOPORT, 1996, p. 170) Os militares que governavam a Argentina eram acusados pelos EUA de conivência com os governos nazifascistas e, por esse motivo, cogitou-se, inclusive, que o país não deveria participar da ONU. (LANGLEY,

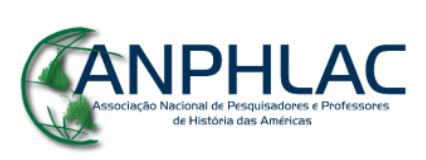

Revista Eletrônica da ANPHLAC, ISSN 1679-1061, №. 22, p. 231-257, Jan./Jun., 2017.

http://revista.anphlac.org.br 
1989, p. 157) A Argentina só rompeu relações diplomáticas com os países do Eixo em janeiro de 1944, e até a Conferência de Chapultepec ainda não havia declarado guerra ao Eixo.

Uma peça-chave na pressão dos EUA pela exclusão da Argentina do sistema interamericano foi a publicação, em fevereiro de 1946, do "Blue Book on Argentina" (a partir de agora, Livro Azul). O Livro Azul foi elaborado pelo Departamento de Estado dos EUA entre outubro de 1945 e fevereiro de 1946, e em seu texto, distribuído para todas as embaixadas do Continente na forma de um memorando de cinquenta e oito páginas, encontramos acusações de cooperação do governo argentino com os países do Eixo, desde a presidência de Ramón Castillo. ${ }^{2}$ O Livro Azul normalmente é mencionado pela literatura especializada (BANDEIRA, 2010, p. 225) apenas como uma peça de propaganda do governo dos EUA para evitar a vitória de Juan Domingo Perón nas eleições de 1946. No entanto, defendemos que seus objetivos eram mais amplos. Visava afastar a Argentina do Sistema Interamericano, o que só não ocorreu em função da reação das outras repúblicas do continente, em especial o Brasil, que seria a sede da Conferência de 1947, e era reconhecido como um aliado fiel da diplomacia dos EUA. Mas, apesar disso, o Brasil contribuiu para minimizar a repercussão e os efeitos da divulgação do Livro Azul.

\section{A Conferência de Chapultepec e a reaproximação da Argentina}

A Conferência de Chapultepec, realizada entre fevereiro e março de 1945, foi convocada pelo governo do México. Os principais objetivos da conferência eram: 1 . propor a criação de um sistema de defesa interamericano, independentemente do que viesse a surgir com a criação da ONU; 2. criar um programa de ajuda econômica para o desenvolvimento da América Latina no pós-guerra; 3. trazer a Argentina para uma posição de cooperação com os Aliados. Havia também o desejo por parte dos países latino-americanos de obter uma vaga permanente no Conselho de Segurança da ONU. Contudo, parece que essa demanda atendia mais a pretensões do governo Roosevelt, que o governo Truman não encampou, e do governo do Brasil - que pretendia ocupar essa vaga - do que uma demanda continental. (GARCIA, 2011)

\footnotetext{
${ }^{2}$ Blue book on Argentina: consultation among the American republics with respect to the Argentine situation: memorandum of the United States government, Washington, D.C., February 1946, p. 1.
}

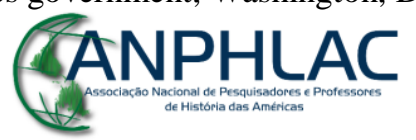

Revista Eletrônica da ANPHLAC, ISSN 1679-1061, №. 22, p. 231-257, Jan./Jun., 2017.

http://revista.anphlac.org.br 
Os Estados Unidos participaram da conferência, mas mantinham restrições sobre a conveniência de formar um mecanismo de defesa continental, o que demonstra uma estratégia diferenciada para o continente americano, pois o modelo proposto pelos países da América antecipou em alguns aspectos o Pacto da Organização do Tratado do Atlântico Norte. Também, com relação a um sistema de ajuda econômica para o desenvolvimento da América Latina, a postura americana foi reticente. O governo dos EUA manteve uma defesa do livre comércio e de investimentos privados como solução para o desenvolvimento e esse assunto volta a aparecer nas Conferências do Rio de Janeiro em 1947 e em Bogotá em 1948, sem resultados expressivos. (GONÇALVES, 2011)

Provavelmente, o motivo que levou o governo do México a convocar a Conferência de 1945, de certa forma passando por cima da autoridade da União Panamericana, foi o já mencionado problema argentino. Os EUA não aceitavam participar da Conferência com a presença de um país que ainda não havia declarado guerra ao Eixo. Por outro lado, seria bastante problemático à União Pan-americana realizar uma conferência sem a participação de um destacado membro como a Argentina. O caráter excepcional de Chapultepec permitiu convidar a Argentina, mas realizar a conferência mesmo sem a sua participação. (CASTRO, 2007) ${ }^{3}$ Embora a Argentina não tenha participado da conferência, dias depois do seu encerramento o país declarou guerra ao Eixo e assinou a Ata do México, no início de abril. Como recompensa, foi admitida para participar da Conferência de São Francisco que aprovou a criação da ONU, ainda que seu convite definitivo tenha enfrentado uma forte resistência por parte da URSS. (RAPOPORT, 1996, p. 176)

Reaceito na "família pan-americana", o governo de Farrell tomou algumas medidas contrárias aos interesses do Eixo. Fechou jornais que eram claramente fascistas, finalmente declarou que os tripulantes do Graf Spee ${ }^{4}$, que haviam se abrigado

\footnotetext{
3 Para um breve histórico da origem da União Pan-americana e suas conferências, ver: CASTRO, Fernando L. V. O pan-americanismo em jogo. Revista de História da Biblioteca Nacional. Rio de Janeiro, jul. 2007, p. 18-21.

${ }^{4}$ Graf Spee foi um navio de guerra alemão que patrulhava o Atlântico Sul no final de 1939 com a ordem de afundar navios mercantes ingleses. No dia 13 de dezembro de 1939, ao se aproximar do estuário do Rio da Prata, o Graf Spee encontrou três navios de guerra ingleses que o alvejaram. Mesmo avariado, o Graf Spee conseguiu navegar até o Porto de Montevidéu, onde pediu permissão para atracar, o que obteve, mas sem autorização para realizar reparos. O governo do Uruguai, pressionado pelos aliados, determinou que o navio alemão deixasse o Porto de Montevidéu, porém os navios ingleses estavam a sua espera e o Capitão preferiu afundar o Graf Spee e pedir asilo no Uruguai. Mas, logo depois, boa parte da
}

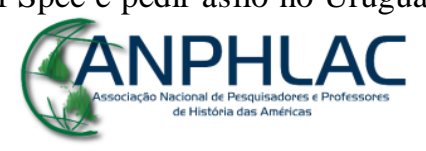

Revista Eletrônica da ANPHLAC, ISSN 1679-1061, №. 22, p. 231-257, Jan./Jun., 2017.

http://revista.anphlac.org.br 
na Argentina, eram prisioneiros de guerra e assumiu o controle de algumas empresas que eram propriedades de alemães. Por sua vez, os Estados Unidos cancelaram as restrições ao comércio externo da Argentina, que tinham sido estabelecidas depois do Golpe Militar de 1943, e chegaram a enviar para o país uma missão diplomática e militar para estudar a cooperação bilateral. (MACDONALD, 1980) Contudo, seria uma precipitação imaginar que Chapultepec realmente encerrou o conflito entre a Argentina e os EUA e suas repercussões na América Latina do pós-guerra.

\section{A Doutrina Larreta e o "Livro Azul"; os EUA pressionam a Argentina}

Ao contrário da conferência de Chapultepec, a Conferência do Rio de Janeiro foi convocada pela União Pan-americana. A carta de Chapultepec previa, no seu artigo IX, a realização de uma próxima Conferência no ano seguinte em Bogotá. ${ }^{5}$ Entretanto, durante a Conferência de São Francisco, por sugestão do Secretário de Estado dos EUA, ficou decidido que a Conferência Interamericana para a Manutenção da Paz e Segurança seria no Rio de Janeiro, em final de outubro de $1945^{6}$, enquanto a Conferência de Bogotá, que iria ratificar a criação da Organização dos Estados Americanos, foi transferida para 1948. Porém, no início de outubro de 1945, a Conferência do Rio de Janeiro foi adiada pela primeira $v^{7} z^{7}$, a pedido dos Estados Unidos, e remarcada para Março de 1946, mas novamente ocorreu um adiamento. Em ambos os casos, o motivador dos adiamentos foi o "problema argentino". Outubro de 1945 coincide com a indicação de Spruille Braden para a subsecretaria de Estado e o início da elaboração do "Livro Azul”, cuja divulgação determinou o segundo adiamento da Conferência.

A recente aproximação do governo dos EUA para com a Argentina parece ter sido seriamente afetada por algumas mudanças que ocorreram entre 1945 e 1946 . A morte de Roosevelt, com a consequente subida ao poder de Truman e a perda da

tripulação do Graf Spee, num episódio até hoje muito obscuro, fugiu para a Argentina e alguns ainda estavam lá até o momento citado. Ver http://viajes.elpais.com.uy/2011/08/12/graf-spee-\%C2\%BFdondefueron-sus-tripulantes/, consultado em 05 de janeiro de 2015.

${ }^{5}$ Inter-American System. International Organization. Vol. 1, No. 3 (Sep., 1947), p. 541.

${ }^{6}$ Memorando para Sua Excelência o Senhor Presidente da República sobre os antecedentes da "Conferência para a Manutenção da Paz e Segurança no Continente". João Carlos Muniz, enviado em 18 de Agosto de 1945. Lata 1797, Arquivo Histórico do Itamaraty (AHI). A confirmação do Rio de Janeiro como sede foi feita na reunião da União Pan-americana, em 26 de Setembro de 1945. Delegação junto a União Pan-americana, ofício de outubro de 1946, anexo 2. Lata 1797, AHI.

${ }^{7}$ Correio da Manhã, Rio de Janeiro, 6 de outubro de 1945, p. 1.

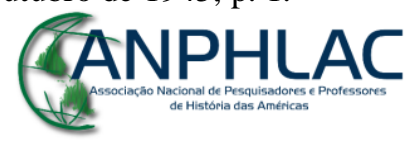


influência de Nelson Rockefeller que, como subsecretário para assuntos latinoamericanos, era um grande defensor da integração da Argentina no Sistema Interamericano e principalmente a nomeação de Spruille Braden, antigo embaixador dos EUA na Argentina, para a Subsecretaria de Estado para assuntos latino-americanos, contribuíram para deteriorar a relação entre os dois países. (RAPOPORT, 1996, p. 176)

O novo governo americano tentou novamente isolar a Argentina, mesmo antes da divulgação do Livro Azul. Em finais de 1945, o Ministro das Relações Exteriores do Uruguai, Eduardo Rodriguez Larreta, apresentou para os governos da América uma proposta que poderia ser incorporada ao futuro pacto interamericano de ajuda recíproca e que ficou conhecida como Doutrina Larreta. O chanceler uruguaio defendia que em casos de ameaças à democracia e aos direitos humanos, justificava-se uma intervenção, inclusive militar, por parte dos países do continente para defender a democracia. (SALAZAR, 2002)

Alguns historiadores atribuem o aparecimento da Doutrina Larreta à influência de Spruille Braden - nesse momento, já promovido para o cargo que antes fora de Nelson Rockefeller - sobre o chanceler Uruguaio. (LANGLEY, 189, p. 164) ${ }^{8}$ Acusações de que o chanceler Uruguaio estava servindo aos interesses dos EUA podem ser encontradas até em discursos de Luís Carlos Prestes no Senado Brasileiro. ${ }^{9}$ O que é inquestionável, porém, é que o governo dos EUA oficialmente apoiou a Doutrina Larreta $^{10}$, e essa posição oficial foi interpretada como a tentativa de criar um mecanismo para realizar intervenções em países que fossem rotulados como não democráticos. No contexto de 1945, a principal ameaça à democracia parecia vir de governos simpatizantes do fascismo, categoria em que ainda se podia incluir sem muita dificuldade o governo de Farrell na Argentina. Contudo, como podemos ver nas manifestações de Prestes, havia o temor de que a Doutrina Larreta se voltasse também contra possíveis governos simpatizantes do comunismo. Temor que não parecia ser

${ }^{8}$ LANGLEY, Lester. America and the Americas, Op. Cit., p. 164. Ver também TRASK, Roger R. The Impact of the Cold War on U.S.-Latin American Relations, 1945-1949. In: LAROSA, Michael; MORA, Frank O. Neighborly Adversaries: Readings in U.S.-Latin American Relations. Baltimore: The Johns Hopkins Press, 1996, p. 134.

9 PRESTES, Luís Carlos. Contra a Guerra e o Imperialismo. Anais da Assembleia Constituinte, vol. 5, 26-03-1946. O discurso também pode ser consultado em: http://www.marxists.org/portugues /prestes/1946/03/26.htm

${ }^{10}$ Radio Broadcast with Assistant Secretary Braden, Director of the Office of American Republic Affairs, Ellis O. Briggs, and the Director of NBC University of the Air, Sterling Fisher, "What is Our InterAmerican Policy?" State Department Bulletin (Volume XIV, No.341, January 6th 1946), p. 26. Pode ser consultado em: https://archive.org/stream/departmentofstat141946unit\#page/26/mode/2up

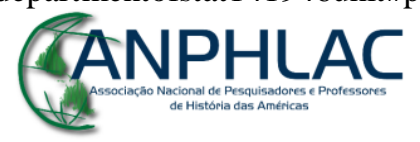

Revista Eletrônica da ANPHLAC, ISSN 1679-1061, №. 22, p. 231-257, Jan./Jun., 2017.

http://revista.anphlac.org.br 
compartilhado pelo Partido Comunista da Argentina (PCA) que, ao contrário do similar brasileiro, sempre defendeu a ideia de que o Governo Farrel-Perón era fascista e pareceu disposto a buscar as mais variadas alianças para derrotá-lo, como demonstra o comportamento do partido nas eleições de 1946. (RAPOPORT, 1996, p. 174) Veremos adiante que a posição de Luís Carlos Prestes sobre o Livro Azul também diferiu da posição de um dos principais líderes do PCA, Rodolfo Ghioldi.

A Doutrina Larreta não encontrou apoio entre a grande maioria dos países latino-americanos. (LANGLEY, 1989, p.174) Parece ter prevalecido o temor de que ela poderia servir para legitimar políticas intervencionistas por parte dos EUA no continente. Contudo, como veremos adiante, durante a Conferência do Rio de Janeiro, ela voltou a ser apresentada. $\mathrm{O}$ relativo insucesso da proposta do chanceler uruguaio também não parece ter desestimulado o governo dos EUA a tentar eliminar a ameaça do governo Farrell.

Em fevereiro de 1946, faltando menos de duas semanas para as eleições na Argentina, o Departamento de Estado dos EUA publicou o Livro Azul. O coronel Juan Domingo Perón era o candidato governista que estava disputando as eleições com o candidato da União Democrática, José P. Tamborini. Na Argentina, parece que o principal efeito da divulgação do Livro Azul foi facilitar a vitória de Perón, que se colocou na posição de um perseguido pelo imperialismo dos EUA e lançou o slogan de campanha: Perón X Braden, sugerindo que o povo Argentino deveria escolher o nacionalismo ou os interesses do Subsecretário de Estado dos EUA. (RAPOPORT, 1996, p. 176) Perón também lançou uma resposta formal, o Livro Azul e Branco, com as mesmas cinquenta e oito páginas do original, fazendo uma série de acusações ao secretário Braden. A vitória de Perón com 56\% dos votos indica que, como peça eleitoral, o Livro Azul fracassou. Contudo, o Livro Azul era bem mais que isso. Nele, podemos encontrar acusações que remontam ao governo de Ramón Castillo, que governou a Argentina entre junho de 1942 e junho de 1943. Podemos também encontrar sérias acusações sobre o comportamento internacional da Argentina com grande potencial de afetar as relações do país com o resto do Continente.

Já na introdução do Livro Azul, o Departamento de Estado indica que o mesmo é uma peça no tabuleiro diplomático. Os editores afirmam que em três de outubro de 1945, o departamento de Estado iniciou uma consulta às Repúblicas da América sobre a

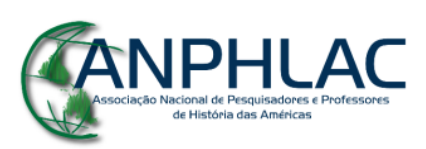


situação da Argentina. Fica sugerido que essas Repúblicas poderiam ter contribuído com informações para a elaboração do dossiê sobre a Argentina. Mas a principal fonte de informações é citada logo em seguida: funcionários do governo alemão e italiano que participavam das relações com a Argentina e foram interrogados a mando do Departamento de Estado. Sem dúvida, muitas outras agências do próprio governo americano também forneceram dados.

As principais informações e conclusões do Livro Azul são listadas já na introdução ${ }^{11}$, o que facilita a nossa síntese e por isso é válido mencioná-las. As cinco afirmações são:

1. Membros do governo militar colaboraram com agentes inimigos para espionagem e outros propósitos prejudiciais para o esforço de guerra da Organização das Nações Unidas;

2. Líderes nazistas, grupos e organizações relacionaram-se com grupos totalitários argentinos com objetivo de criar um Estado Nazifascista;

3. Membros do regime militar que controlavam o governo desde junho de 1943 conspiraram com o inimigo para enfraquecer os governos dos países vizinhos com o objetivo de eliminar a sua colaboração com os Aliados e buscaram alinhá-los com um bloco pró-Eixo;

4. Sucessivos governos argentinos protegeram os interesses econômicos inimigos com o objetivo de preservar o poder industrial e comercial do Eixo na Argentina;

5. Sucessivos governos argentinos conspiraram com o inimigo para obter armas da Alemanha. ${ }^{12}$ (Blue Book on Argentina, p. 1. Tradução do autor)

Seguem-se as conclusões:

1. O Governo Castillo e ainda mais o atual regime militar mantiveram uma política de efetiva ajuda ao inimigo;

2. Os compromissos solenes de cooperar com as outras repúblicas americanas foram completamente violados e comprovadamente foram assumidos para proteger e manter os interesses do Eixo na Argentina;

3. As políticas e ações dos últimos regimes na Argentina foram destinadas a desestabilizar o Sistema Interamericano;

${ }^{12}$ No original:

1. Members of the military government collaborated with enemy agents for important espionage and other purposes damaging to the war effort of the United Nations;

2. Nazi leaders, groups and organizations have combined with Argentine totalitarian groups to create a Nazi-Fascist state;

3. Members of the military regime who have controlled the government since June, 1943, conspired with the enemy to undermine governments in neighboring countries in order to destroy their collaboration with the Allies and in an effort to align them in a pro-Axis bloc;

4. Successive Argentine governments protected the enemy in economic matters in order to preserve Axis industrial and commercial power in Argentina;

5. Successive Argentine governments conspired with the enemy to obtain arms from Germany.

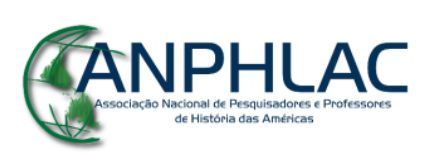

Revista Eletrônica da ANPHLAC, ISSN 1679-1061, №. 22, p. 231-257, Jan./Jun., 2017.

http://revista.anphlac.org.br 
4. Os indivíduos e grupos totalitários, tanto militares como civis, que controlam o atual governo na Argentina, vem, juntamente com os seus colaboradores nazistas, perseguindo um objetivo comum: A criação neste Hemisfério de um estado totalitário. Este objetivo já foi parcialmente alcançado;

5. Cada vez mais, desde a invasão da Normandia, e mais obviamente desde o fracasso da última contraofensiva alemã em janeiro de 1945, o regime militar recorreu a uma estratégia defensiva de camuflagem. A aceitação das obrigações da Conferência Interamericana sobre Problemas da Guerra e da Paz para acabar com a influência nazista e as repetidas confirmações de intenções democráticas serviram a esta estratégia de camuflagem;

6. Por seu uso brutal da força e de métodos terroristas para derrubar toda a oposição do povo argentino o regime militar transformou em zombaria seu compromisso com as Nações Unidas de reafirmar a fé nos direitos humanos, na dignidade e no valor do ser humano pessoa. (Blue Book on Argentina, p. 2. Tradução do autor) ${ }^{13}$

É fácil perceber que a grande maioria das informações e conclusões tem fortes implicações diplomáticas. Governos da Argentina, desde pelo menos 1942, foram acusados de prejudicar os esforços de guerra das Nações Aliadas, buscar atrair países vizinhos para à órbita do Eixo, buscar o fornecimento de armas na Alemanha. Mas, principalmente, a Argentina é acusada de minar as ações em prol do sistema interamericano, buscar criar Estados totalitários no hemisfério e explicitamente agir no âmbito das Nações Unidas e no Continente de forma dissimulada. O governo da Argentina é diretamente acusado de ter assumido compromissos na Conferência de Chapultepec apenas para camuflar suas reais ligações com o fascismo.

É interessante que na hora de destacar as falhas do governo Argentino em cumprir com os compromissos que o levaram a assinar a Ata de Chapultepec e posteriormente ser aceito como membro da ONU, o Livro Azul use uma citação de

${ }^{13}$ No original:

1. The Castillo Government and still more the present military regime pursued a policy of positive aid to the enemy;

2. Solemn pledges to cooperate with the other American republics were completely breached and are proved to have been designed to protect and maintain Axis interests in Argentina;

3. The policies and actions of the recent regimes in Argentina were aimed at undermining the InterAmerican System;

4. The totalitarian individuals and groups, both military and civilian, who control the present government in Argentina, have, with their Nazi collaborators, pursued a common aim: The creation in this Hemisphere of a totalitarian state. This aim has already been partly accomplished;

5. Increasingly since the invasion of Normandy, and mast obviously since the failure of the last German counter offensive in January, 1945, the military regime has had to resort to a defensive strategy of camouflage. The assumption of the obligations of the Inter-American Conference on Problems of War and Peace to wipe out Nazi influence and the repeated avowals of prodemocratic intentions proceeded from this strategy of deception;

6. By its brutal use of force and terrorist methods to strike down all opposition from the Argentine people the military regime has made a mockery of its pledge to the United Nations "to reaffirm faith in human rights, in the dignity and worth of the human person."

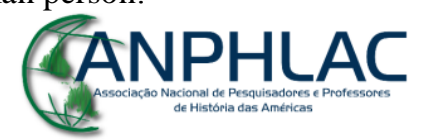

Revista Eletrônica da ANPHLAC, ISSN 1679-1061, №. 22, p. 231-257, Jan./Jun., 2017.

http://revista.anphlac.org.br 
Nelson Rockefeller ${ }^{14}$, amplamente reconhecido como um defensor da participação da Argentina em todos os acordos continentais do pós-guerra. (TOTTA, 2014, p. 148) Em seguida, a Conferência do Rio de Janeiro é explicitamente citada e o texto sugere que o governo dos EUA não poderia aceitar a participação da Argentina na assinatura de um Tratado de Mútua Assistência Recíproca, algo que estava previsto desde Chapultepec. Isto é, em grande parte, o objetivo internacional do Livro Azul foi excluir a Argentina da Conferência do Rio de Janeiro e de todos os compromissos que seriam assumidos na mesma. $^{15}$

Finalizada a introdução, o texto começa a detalhar as denúncias. Para a nossa questão, interessa principalmente observar aquelas acerca das conspirações do governo da Argentina no sentido de manter uma aliança informal com o Eixo e estimular o aparecimento de governos pró-fascistas nos países vizinhos. O Livro Azul relata esforços do governo da Argentina para obter armamento alemão com o objetivo de se defender dos inimigos do Eixo, inclusive de um possível ataque do Brasil, caso a Argentina proclamasse sua aliança com o nazifascismo. Também detalha a famosa missão de Oscar Hellmuth, um alemão naturalizado argentino que viajou para a Alemanha com o objetivo de comprar armamento, mas foi capturado pela Inglaterra enquanto viajava. ${ }^{16}$ Afirma também que o embaixador da Espanha na Argentina, Eduardo Aunós, estudava opções para enviar secretamente o armamento para a Argentina, provavelmente em navios da Espanha. ${ }^{17}$

A principal tese do Livro Azul sobre a postura continental da Argentina é apresentada em seguida, citando como fonte uma "autoridade alemã":

O grande objetivo da política externa da Argentina depois da Revolução de 4 de Junho de 43, foi a formação de um bloco de Estados sul americanos, tendo a Argentina como centro. Esta política estava direcionada principalmente contra os EUA e sua política da boa vizinhança (isto é, contra a solidariedade pan-americana). Este bloco iria envolver Argentina, Chile, Bolívia, Paraguai, Uruguai e possivelmente depois também o Brasil (através da ajuda dos integralistas brasileiros). (Blue Book on Argentina, p. 6. Tradução do autor $^{18}$

\footnotetext{
${ }^{14}$ Blue Book on Argentina, Op. Cit., p. 3.

${ }^{15}$ Blue Book on Argentina, Op. Cit., p. 3.

${ }^{16}$ Blue Book on Argentina, Op. Cit., p. 5. Sobre o caso Hellmuth, ver também NEWTON, Ronald C. The "Nazi menace" in Argentina, 1931-1947. Stanford, Calif.: Stanford University Press, 1992.

${ }^{17}$ Blue Book on Argentina, Op. Cit., p. 6.

${ }^{18}$ No original: "The great goal of Argentine foreign policy after the revolution of the 4 June, 1943 was the formation of a bloc of South American States, whose center Argentine should be. This policy was directed principally against the USA and its Good Neighbor policy (that is, against Pan-American
}

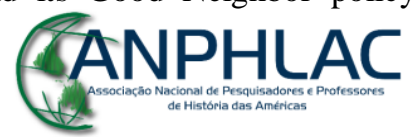

Revista Eletrônica da ANPHLAC, ISSN 1679-1061, №. 22, p. 231-257, Jan./Jun., 2017.

http://revista.anphlac.org.br 
Em seguida, o texto detalha a conspiração para atrair os países vizinhos para a esfera do Eixo, afirmando que o principal responsável por sua operação era o Coronel Juan Domingo Perón. O primeiro país mencionado é a Bolívia, e os principais acusados de trabalhar para instalar um governo nazifascista no país foram o Major Elias Belmonte Pabon, militar que participou da tentativa de golpe de Estado em 1941, e Dionisio Foianini Banzer, Ministro das Minas e Petróleo no governo de Germán Busch. Contudo, o contato direto com o governo da Argentina teria sido feito por Victor Paz Estenssoro $^{19}$, Ministro do Gabinete do presidente Gualberto Villarroel, e que posteriormente foi presidente da Bolívia por quatro mandatos. Talvez a Bolívia seja citada em primeiro lugar porque o Livro Azul implica seriamente o governo de Gualberto Villarroel, seria um caso onde a aliança Argentina-Alemanha teria funcionado para impor um governo pró-fascista. (ZANATTA, 2006) ${ }^{20}$

Em seguida, o Livro Azul trata do Brasil, o que nos desperta maior interesse, uma vez que essas acusações poderiam ter efeito grande na postura do governo brasileiro sobre a participação da Argentina sob o governo de Perón no sistema interamericano. Basicamente, o Livro Azul acusa o governo de Perón de ter procurado contato com integralistas que estavam refugiados na Argentina em 1943. São nominalmente citados o militar Jair Tavares e um "Dr. Caruso", provavelmente o dentista Francisco Caruso Gomes. Posteriormente, Raimundo Padilha teria sido acionado e enviado para Buenos Aires o Major Jaime Ferreira da Silva, que teria negociado diretamente com Perón. Então, são listados os objetivos do acordo entre o governo da Argentina e os integralistas brasileiros: ampliar a propaganda favorável ao Eixo em português, aproximar Padilha do Adido Militar da Argentina no Rio de Janeiro, permitir que os integralistas usassem a comunicação diplomática da Argentina para seus próprios objetivos, implantar agentes secretos sob o disfarce de membros da Câmera de Comércio da Argentina no Brasil, e, finalmente, divulgar propaganda contrária ao governo de Vargas. ${ }^{21}$

solidarity). This bloc was to comprise, Argentina, Chile, Bolivia, Paraguay, Uruguay and possibly later Brazil (through the help of the Brazilian Integralists).

${ }^{19}$ Blue Book on Argentina, Op. Cit., p. 14.

${ }^{20}$ Para uma avaliação bastante diferente das relações entre a Argentina e a Bolívia no período ver: ZANATTA, Loris. The rise and fall of the third position: Bolivia, Perón and the Cold War, 1943-1954. Desarrollo Económico (B. Aires) [online]. 2006, vol. 1, Selected edition.

${ }^{21}$ Blue Book on Argentina, Op. Cit., p. 16.

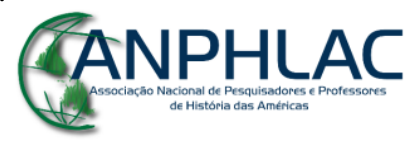


Entre todos os integralistas citados, o mais destacado, sem dúvida, era Raimundo Padilha. Ele parece ter entrado no movimento integralista ainda estudante, mas chegou ao posto de líder regional da Ação Integralista Brasileira no Rio de Janeiro. (TRINDADE, 1979, p. 120) O militar Jaime Ferreira da Silva chegou a ser eleito vereador no Rio de Janeiro pelo PRP (Partido de Representação Popular) em $1947 .^{22}$ Partido fundado em 1945 (CALIL, 2005, p. 226), e que abrigou os principais integralistas. Além de Jaime Ferreira da Silva, Jair Tavares e Raimundo Padilha chegaram a ser membros do PRP. Jair Tavares, ou Jayr Tavares, como os jornais brasileiros da época grafavam, e Francisco Caruso Gomes também não são citados pela literatura especializada no integralismo como destacadas lideranças, que ficaram conhecidos, em 1945, porque foram presos pela polícia da Argentina a pedido do Uruguai, acusados de atividades de propaganda nazista. ${ }^{23}$ Todos os citados negaram envolvimento em atividades favoráveis ao Eixo. O Major Jaime Ferreira da Silva, inclusive, teria mandado um telegrama para o General Góis Monteiro pedindo abertura de inquérito para investigar suas próprias atividades. ${ }^{24}$

O Chile recebe pequeno destaque, o que é, até certo ponto, surpreendente, dado o reconhecido esforço do governo de Perón em buscar uma aproximação com este país. (CAVLAK, 2008, p. 119) Perón é acusado diretamente de ter usado seu cargo de adido militar no Chile, entre 1936 e 1938, para buscar uma aproximação com simpatizantes chilenos do nazifascismo, para os quais teria oferecido, em Janeiro de 1944, uma ajuda de um milhão de dólares, mas o texto sugere que a ajuda não se concretizou.

Finalmente, temos um parágrafo sobre Paraguai e Uruguai, onde são feitas afirmações genéricas sobre a existência de colaboração entre militares argentinos e alemães para estabelecer ramificações nesses países. Nenhum nome é citado. Há um claro contraste entre o detalhamento das acusações que envolvem a Bolívia e o Brasil e os outros três países citados.

O objetivo desse texto não é fazer um exame exaustivo do "Livro Azul", mas destacar os aspectos que envolviam e podiam sensibilizar mais diretamente outras nações do sistema interamericano que estava sendo criado nesse momento. Nas seções

\footnotetext{
${ }^{22}$ A Noite, 29 de janeiro de 1947, p. 2.

${ }^{23}$ A Noite, 24 de janeiro de 1945. Ver também, Correio da Manhã, 09 de janeiro de 1945, p. 1 e Correio da Manhã, 19 de fevereiro de 1946, p. 1. Nesta última edição, encontramos uma entrevista com Francisco Caruso Gomes realizada por Rubem Braga.

${ }^{24}$ O telegrama foi publicado pelo jornal A Noite, 14 de fevereiro de 1946, p. 7.
}

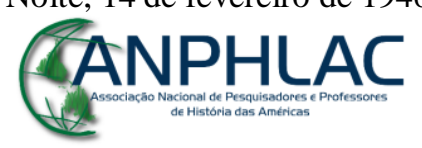

Revista Eletrônica da ANPHLAC, ISSN 1679-1061, №. 22, p. 231-257, Jan./Jun., 2017.

http://revista.anphlac.org.br 
seguintes, o texto passa a se concentrar principalmente no fato de que os governos de Castillo e Farrell teriam mantido durante toda a Segunda Guerra uma política de colaboração com o Eixo, não obstante em alguns momentos cite outras nações do continente e por várias vezes aponte para o apoio da Espanha de Franco como sendo praticamente um terceiro elemento da aliança da Argentina com a Alemanha Nazista.

Podemos resumir as evidências da colaboração com o Eixo num conjunto de acusações, algumas genéricas, como os contatos frequentes de líderes argentinos com representantes do Eixo, outras mais específicas como a proteção governamental fornecida para o estabelecimento de uma rede de espionagem na América do Sul ou os esforços no sentindo de obter armamento na Alemanha, com o objetivo provável de atacar os países vizinhos. O governo argentino também é acusado de proteger as atividades de empresas da Alemanha na Argentina, assim como escolas, jornais e outras instituições, mesmo que fossem cidadãos de nações do Eixo. Finalmente, os generais argentinos são acusados de utilizar a força para calar a oposição e especialmente aqueles que se opunham à aproximação da Argentina com o Eixo. Até mesmo o fato de que a Argentina acordou com a Alemanha a intensificação da propaganda anticomunista é citado como evidência. ${ }^{25}$

Muitas dezenas de nomes são citados nas acusações contidas no Livro Azul. Em nosso texto, não temos, de modo algum, a intenção de discutir a veracidade das denúncias. De um ponto de vista assumidamente subjetivo, avaliamos que muitas delas parecem exageradas e pouco fundamentadas. Entretanto, não deixamos de notar que alguns dos nomes citados vão reaparecer no estudo muito bem documentado de Uki Goñi (2004) sobre a ligação da Alemanha nazista com o governo militar da Argentina. Há pelo menos cinco personagens que têm destaque na obra do historiador argentino e também no Livro Azul: Juan Carlos Goyeneche, Osmar Hellmuth, Enrique Ruiz Guinazú, Johannes Siegfried Becker e Ludwig Freude, além de Perón, é claro. ${ }^{26}$ Ludwig Freude foi um empresário alemão residente na Argentina que aparece entre os “principais personagens" do livro de Goñi $\left(2004\right.$, p. 14) ${ }^{27}$ e mereceu uma página inteira dedicada ao seu caso no Livro Azul. ${ }^{28}$ Não há, evidentemente, uma superposição total,

\footnotetext{
${ }^{25}$ Blue Book on Argentina, Op. Cit., p. 20.

${ }^{26}$ Praticamente os mesmos personagens também aparecem em uma pesquisa anterior a de Goñi: Ronald C. The "Nazi menace” in Argentina, 1931-1947. Stanford, Calif.: Stanford University Press, 1992.

${ }^{27}$ Blue Book on Argentina, p. 14.

${ }^{28}$ Blue Book on Argentina, p. 40.
}

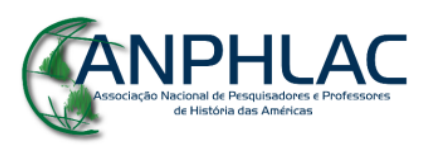


muitas acusações contidas no Livro Azul não encontram eco na pesquisa de Goñi, que, por seu turno, é mais amplo em vários aspectos e desvendou ligações que talvez o Departamento de Estado dos EUA nem imaginasse. O Livro Azul é citado na bibliografia do trabalho de Goñi e pode ter ajudado na sua pesquisa para os capítulos iniciais, mas seu trabalho vai muito além, inclusive, investigando o governo de Perón, que nem havia se iniciado quando o Livro Azul foi publicado.

Voltando ao texto do Livro Azul, antes das conclusões, ainda podemos encontrar uma interessante seção intitulada "As Características Nazifascistas do Regime Argentino". Aberta com uma citação de um discurso de Roosevelt, de setembro de 1944, sobre a situação da Argentina, a seção faz uma espécie de estudo social e político, tentando demonstrar que a nação platina, sob os governos de Castillo e Farrell, transformou-se num Estado totalitário, semelhante àqueles que compunham o Eixo. As evidências são a repressão e o terrorismo estatal, o controle dos sindicatos, a intervenção no sistema educacional, o controle sobre a imprensa, a militarização da sociedade e o aumento dos gastos militares. Do ponto de vista do nosso estudo, contudo, o mais relevante é que em vários momentos o "Livro Azul" compara os procedimentos do governo argentino com o que tinha sido estabelecido pela Ata de Chapultepec, resultado da Conferência Interamericana sobre Problemas da Guerra e da Paz. Como quando cita a Resolução XI da Ata do México que menciona a adesão aos valores democráticos e o respeito aos direitos individuais, para depois caracterizar o Regime Militar Argentino como um estado policial que persegue todos os seus opositores. ${ }^{29}$ Também, quando cita a Resolução XXIX da mesma Ata, sobre a importância de adotar valores democráticos no sistema de ensino, para depois denunciar o controle que o Governo Militar exercia sobre as escolas. ${ }^{30}$ Há um claro objetivo de demonstrar que a Argentina não seguia os ditames estabelecidos na Conferência e, portanto, constituía uma espécie de "pária" no sistema interamericano.

\section{As Repercussões do "Livro Azul" e o impasse em torno da Conferência Internacional para a Manutenção da Paz e da Segurança Continental}

\footnotetext{
${ }^{29}$ Blue Book on Argentina, p. 47.

${ }^{30}$ Blue Book on Argentina, p. 52.
}

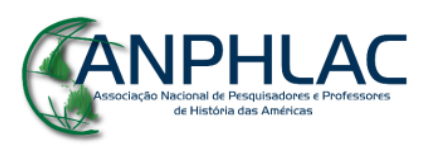


Imediatamente após a divulgação do Livro Azul, começaram as especulações sobre um segundo adiamento da Conferência do Rio de Janeiro, o que, como já mencionamos, concretizou-se no início de Março de 1946. Segundo Iuri Cavlak, a Embaixada brasileira na Argentina recomendou o adiamento "uma vez que não se deve excluir a Argentina da reunião e nem pode recebê-la com agrado.” (CAVLAK, 2008, p. 90) As repercussões das denúncias na imprensa dos EUA e do Brasil foram imensas. No Brasil, fizemos um levantamento mais exaustivo em dois jornais cariocas: o declaradamente oposicionista Correio da Manhã e o situacionista, quase um jornal oficial, A Noite ${ }^{31}$. Curiosamente, as fontes estrangeiras dos dois jornais eram muitas vezes as mesmas.

A revista The Nation, reconhecidamente ligada ao Partido Democrata, pouco depois da divulgação do Livro Azul, publicou uma matéria, assinada por Stanley Ross, intitulada Perón, um Hitler Sul-americano ${ }^{32}$, a qual foi citada por pelo menos um jornal brasileiro. ${ }^{33}$ Poucos dias depois, a revista publicou um perfil bastante elogioso do Secretário Spruille Braden, destacando sua atuação contra o governo da Argentina e contra Perón. ${ }^{34}$ Finalmente, a editora da revista, Freda Kirchwey, enviou uma carta para o Conselho de Segurança da ONU, em papel timbrado da revista, onde reproduziu trechos do "Livro Azul" e pediu a exclusão da Argentina da Organização. ${ }^{35}$

A carta da editora para a ONU e a grande quantidade de matérias na revista contra Perón, várias antes mesmo da publicação do Livro Azul, caracterizam praticamente uma campanha do veículo. Contudo, outros veículos informaram sobre a publicação do Livro Azul e sua repercussão, reverberando na imprensa brasileira. $\mathrm{O}$ jornal A Noite, além da Revista The Nation, cita matéria assinada por repórter da United Press, em Londres, mencionando a expectativa de que alguma delegação, provavelmente a da URSS, pediria a exclusão da Argentina da ONU. ${ }^{36}$ A mesma

\footnotetext{
${ }^{31}$ Ver Dicionário Histórico-Biográfico Brasileiro Pós-1930. FGV-CPDOC. Verbetes Correio da Manhã e A Noite.

32 The Nation, 16 de fevereiro de 1946, p. 189-194.

${ }^{33}$ A Noite, 14 de fevereiro de 1946, capa e p. 7.

${ }^{34}$ The Nation, 23 de fevereiro de 1946, p. 215-219.

${ }^{35}$ Freda Kirchwey to Dr. Quo Tai-chi, President of the Security Council United Nations Organization, Bronx, New York, 27 de Março de 1946. Herbert H. Lehman Papers, Special Correspondence Files, Rare Book and Manuscript Library, Columbia University Library. Disponível em: http://www.columbia.edu/cu/lweb/digital/collections/rbml/lehman/pdfs/0488/ldpd_leh_0488_0012.pdf Acesso em: 29/12/2014.

${ }^{36}$ A URSS não formalizou o pedido de exclusão da ONU, embora pouco tempo antes tenha se oposto à participação da Argentina na instituição. Talvez, a mudança de posição esteja relacionada ao fato de que a
}

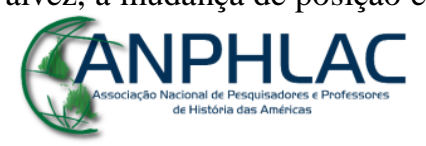

Revista Eletrônica da ANPHLAC, ISSN 1679-1061, №. 22, p. 231-257, Jan./Jun., 2017.

http://revista.anphlac.org.br 
matéria afirma que a delegação dos EUA não faria o pedido formal. ${ }^{37} \mathrm{Na}$ edição do dia seguinte, citando um correspondente do Daily Mail, o jornal vai ainda mais longe e prevê o rompimento das relações entre EUA e Argentina. ${ }^{38}$ No dia 15 de fevereiro, novamente usando como fonte principal a United Press, mas também o jornal La Nación, A Noite começa a tratar da resposta Argentina e informa que os EUA não iriam romper relações com a Argentina. ${ }^{39}$ Sobre o rompimento das relações, parece que a estratégia dos EUA era esperar a reação das outras repúblicas para, talvez, propor um rompimento coletivo. ${ }^{40}$ No dia 18 de fevereiro, usando principalmente a Associated Press, A Noite trata do Discurso do Embaixador Argentino na ONU e da tréplica do Departamento de Estado dos EUA sob o título "A verdade dói" são citados dois editoriais, um do New York Times e outro do The Repository de Ohio, ambos defendendo a pertinência de publicar o Livro Azul. ${ }^{42}$ Mas A Noite não se limitava a reproduzir notícias estrangeiras. Além de buscar apurar as denúncias contra os integralistas brasileiros, seu colunista, Nemo Canabarro, defendeu a exclusão da Argentina da ONU e da Conferência do Rio de Janeiro. ${ }^{43}$

O jornal Correio da Manhã também começou a mencionar o Livro Azul na sua edição de 13 de fevereiro, usando como fonte um jornalista da Associated Press que também serviu de fonte para matérias do jornal A Noite. ${ }^{44}$ No dia seguinte, o Correio reproduz trechos do New York Times e do Herald Tribune, que teriam dado bastante destaque para matérias sobre o Livro Azul. ${ }^{45}$ Mas o Correio da Manhã produziu um interessante material próprio, enviando o mesmo Rubem Braga, que entrevistou o Dr. Caruso, para Buenos Aires, onde ele obteve uma entrevista com o líder comunista Rodolfo Ghioldi. Na entrevista, percebemos que Ghioldi apoiou claramente as denúncias do Livro Azul e declarou que "o Peronismo é fascismo" e que a vitória de

URSS e a Argentina estavam nesse momento negociando o reatamento de suas relações diplomáticas. Segundo Rapoport, com intermediação de Prestes. Ver RAPOPORT, Mario. Política y Diplomacia en la Argentina, las relaciones con EE.UU. y la URSS. Buenos Aires: Editorial Tesis, 1987, p. 24, 25.

37 A Noite, 13 de fevereiro de 1946, capa, p. 7, 8.

${ }^{38}$ A Noite, 14 de fevereiro de 1946, p. 3.

39 A Noite, 15 de fevereiro de 1946, p. 2.

${ }^{40}$ Office of the historian. Disponível em: https://history.state.gov/historicaldocuments/frus1946v11/d206 Acesso em: 08 de abril de 2015.

${ }^{41}$ A Noite, 18 de fevereiro de 1946, p. 1.

42 A Noite, 18 de fevereiro de 1946, p. 14.

${ }^{43}$ A Noite, 14 de fevereiro de 1946, p. 10.

${ }_{44}^{44}$ Correio da Manhã, 13 de fevereiro de 1946, capa e p. 3.

${ }^{45}$ Correio da Manhã, 14 de fevereiro de 1946, capa e p. 3.

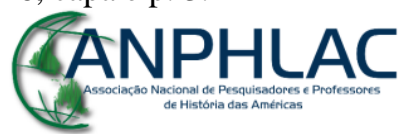


Perón poderia significar a necessidade de uma nova guerra para restaurar a democracia no país. Quase ao mesmo tempo, Luis Carlos Prestes declarava que o Livro Azul era uma manobra imperialista dos EUA para dividir e subjugar os países latinoamericanos. $^{46}$

O Correio da Manhã registrou que o Livro Azul repercutiu na Assembleia Constituinte, tendo sido votado um requerimento para exigir que o poder executivo tomasse providências acerca das denúncias. ${ }^{47} \mathrm{O}$ Correio da Manhã também noticiou a resposta de Perón ao Departamento de Estado, mas, na mesma edição, mencionou a publicação por parte da Revista Life de uma foto de Perón jantando com Rudolph Freude, filho de Ludwig Freude, já mencionado aqui, e acusado no Livro Azul de ser uma das principais ligações do governo argentino com o governo nazista. ${ }^{48}$ Ao comentar mais detidamente o Livro Azul e branco (a resposta de Perón ao Livro Azul) em coluna na capa do jornal, Rubem Braga afirma que as denúncias do Livro Azul “continuam de pé”, ainda que não se possa confirmar a veracidade de todas elas. Para o jornalista, a resposta de Perón foi frágil. Sua estratégia foi, para aquilo que era difícil negar, jogar a responsabilidade totalmente nas costas do Presidente Castillo, sem envolvimento de Farrell e Perón, e, na maior parte da réplica, acusar Braden de defender interesses escusos, corruptos e imperialistas. O jornalista não deixou de notar que o Livro Azul e branco cita mais de uma vez as afirmações de Luis Carlos Prestes em defesa do regime argentino. ${ }^{49}$ Não nos aprofundaremos no contraste entre o Livro Azul e o Livro Azul e Branco porque, na documentação diplomática, o segundo praticamente não é citado, porém, Rubem Braga parece ter feito uma leitura bastante atenta da réplica de Perón.

\section{A Reação do Itamaraty, das outras Repúblicas Latino-Americanas e o recuo dos EUA}

$\mathrm{Na}$ primeira manifestação oficial registrada pela imprensa, o chanceler brasileiro, João Neves da Fontoura, evitou manifestar um posicionamento claro sobre as denúncias do Livro Azul, limitando-se a reiterar a ligação histórica com os EUA, mas

\footnotetext{
${ }^{46}$ A Noite, 15 de fevereiro de 1946 , p. 3.

${ }^{47}$ Correio da Manhã, 20 de fevereiro de 1946.

${ }^{48}$ Correio da Manhã, 23 de fevereiro de 1946, capa.

${ }^{49}$ Correio da Manhã, 01 de Março de 1946, capa.
}

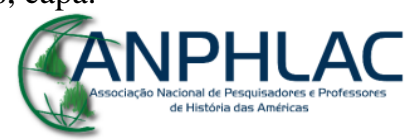


também a política de manter a união e a solidariedade pan-americana. ${ }^{50}$ Para o chanceler, nem mesmo adiar a Conferência do Rio de Janeiro seria necessário; a Conferência poderia ocorrer com a presença da Argentina, algo que os EUA não estavam dispostos a aceitar naquele momento. Sabemos que o adiamento ocorreu. No Brasil, a consequência mais imediata do Livro Azul foi que o governo avisou à Espanha que não aceitaria o Embaixador Eduardo Aunós como seu representante no país. Aunós já estava em viagem para assumir a Embaixada no Brasil, porém, o diplomata, que antes atuou na Argentina, foi citado várias vezes no Livro Azul como um facilitador dos contatos entre os governos da Argentina, Espanha e Alemanha. ${ }^{51}$ Seu agrément foi cancelado e logo depois ele foi declarado "persona non grata".

Um novo posicionamento do chanceler brasileiro só aparece no início de Abril na forma de uma entrevista coletiva. O próprio João Neves fez questão de enviar para Getúlio Vargas, anexada a uma carta pessoal, recortes de jornal noticiando sua entrevista. O fato de que o chanceler, Ministro do Governo Dutra, mantivesse Getúlio Vargas tão informado, indica que sua lealdade continuava com Vargas, mesmo no momento em que cresciam as divergências entre o getulista e o governo Dutra. Na carta, João Neves comenta como sua posição ficou difícil frente ao duelo Perón X Braden, no qual foi preciso dosar os compromissos com os EUA e nossa tradição contrária ao intervencionismo. João Neves admite que tentou de todo modo adiar um pronunciamento oficial até o resultado das eleições na Argentina. Também admite que, antes de divulgar o texto final, pediu ao embaixador do Brasil nos EUA, Carlos Martins, que o submetesse à apreciação do Secretário de Estado dos EUA. Mais que isso, o chanceler sugere que autorizou o embaixador a negociar qualquer modificação na forma do pronunciamento, caso o governo dos EUA não concordasse com ela, "mas não no conteúdo". O chanceler ficou satisfeito com a repercussão na imprensa, mesmo "a comunista" e também a da Argentina. Na carta, encontramos anexados recortes do Jornal do Brasil, Correio da Manhã, Tribuna Popular e Jornal do Comércio. ${ }^{52}$

\footnotetext{
50 A posição "vacilante" do chanceler foi atacada pelo jornal Correio da Manhã em 20 de fevereiro de 1946, p. 3.

${ }^{51}$ A Noite, 19 de fevereiro de 1946, p. 9.

${ }^{52}$ Carta de João Neves a Getúlio Vargas sobre política internacional, relações entre Argentina-Estados Unidos, posição do Brasil frente ao conflito entre estas duas nações etc. Arquivo Getúlio Vargas, CPDOC, GV c 1946.04.06, rolo 9 fot. 0118 a 0120.
}

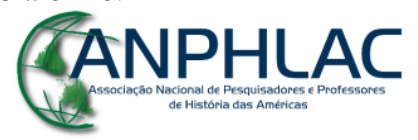


O conteúdo do pronunciamento do Itamaraty foi reproduzido quase integralmente por todos esses jornais, explicitando-se a posição brasileira de minimizar as denúncias contidas no Livro Azul e caracterizando-as como ultrapassadas pela nova realidade do pós-guerra. Após afirmar que partilhava das preocupações do governo dos EUA, a nota do Itamaraty pondera que:

consumada a vitória militar das Nações Unidas contra o Eixo totalitário, as revelações do referido relatório - todas concernentes a atividades desenvolvidas pelo inimigo ou outros governos de atitude então indefinida perdem, em parte, sua temibilidade. (NEVES DA FONTOURA, CPDOC, 1946)

Mais interessante ainda é verificar que a posição divulgada pelo Itamaraty para a imprensa brasileira foi bastante coerente com a resposta oficial que o Ministério das Relações Exteriores do Brasil forneceu para seu equivalente estadunidense sobre o mesmo tema. Essencialmente, o Brasil reafirmou que a conjuntura era muito diferente e ainda destacou que o fato dos EUA possuírem a bomba atômica mudou drasticamente as relações de poder no mundo. ${ }^{53}$

Sobre a participação da Argentina na Conferência do Rio de Janeiro, a nota afirma:

o governo brasileiro reafirma o seu empenho para que seja assinado tão cedo quanto possível, o pacto de assistência mútua entre as nações do hemisfério. Evidentemente, o referido instrumento só terá valor efetivo na obra de consolidação da paz se for subscrito pela totalidade das nações americanas. ${ }^{54}$

Finalmente, sobre as relações do Brasil com a Argentina e a nova realidade póseleitoral, a nota afirma:

de vez que todos os partidos argentinos empenhados no último pleito timbraram em proclamar que foi livre e escorreito o pronunciamento popular, o nosso País continuará as relações diplomáticas habituais com o Governo que sair da apuração eleitoral na grande nação do sul do Continente. ${ }^{55}$

Apesar dos cuidados para não ofender a posição dos EUA, a mensagem é clara. O governo brasileiro considerava que o sentido das denuncias havia caducado em função do final da guerra e também da eleição democrática de Perón - no momento da

53 FOREIGN RELATIONS, 1946, VOLUME XI. Disponível em: http://digicoll.library.wisc.edu/cgibin/FRUS/FRUS-idx?type=turn\&entity=FRUS.FRUS1946v11.p0026\&id=FRUS.FRUS1946v11\&isize= text Acesso em: 10 de maio de 2016.

${ }^{54}$ Idem, e também, Correio da Manhã, 05 de abril de 1946, p. 2.

55 Idem, e também, Correio da Manhã, 05 de abril de 1946, p. 2.

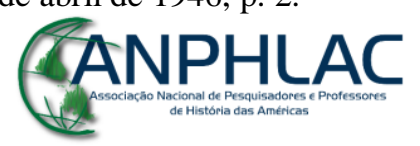

Revista Eletrônica da ANPHLAC, ISSN 1679-1061, №. 22, p. 231-257, Jan./Jun., 2017.

http://revista.anphlac.org.br 
divulgação da nota, o estágio da apuração indicava claramente a vitória de Perón-, e a Conferência do Rio de Janeiro precisava contar com a participação da Argentina.

Mesmo entre os recortes selecionados pelo próprio chanceler, é possível perceber pelo menos uma contestação. O jornalista da Tribuna Popular questionou João Neves sobre a incoerência de negar o agrément para o embaixador da Espanha, Eduardo Aunós, e não tomar nenhuma atitude sobre os integralistas denunciados pelo Livro Azul. João Neves se limitou a responder que o governo não estava preocupado com a ação dos integralistas, o que era coerente com o esforço em minimizar as denúncias do Livro Azul. ${ }^{56}$

Pouco depois dessa entrevista, A Noite informa - usando como fonte a Associated Press que, por sua vez, cita um porta-voz do departamento de Estado dos EUA - que dez repúblicas tinham se manifestado sobre as denúncias do Livro Azul: Brasil, Chile, Colômbia, Costa Rica, Equador, Guatemala, México, Nicarágua, Peru e Uruguai, mas que as manifestações eram confidenciais. ${ }^{57}$ Porém, alguns dias depois, o Departamento de Estado publicou uma nota com uma espécie de resumo das respostas obtidas, menos da metade dos países do continente teriam respondido, alguns concordando integralmente com a posição do EUA, outros afirmando que o resultado das eleições mudou o panorama. Sabemos que o Brasil foi um dos países que se posicionou entre aqueles que defendiam que as denúncias estavam ultrapassadas. ${ }^{58}$ Analisando os documentos publicados pelo Ministério das Relações Exteriores do EUA, encontramos posições contrárias aos interesses dos EUA também por parte do Equador $^{59}$, México ${ }^{60}$, Chile $^{61}$, Cuba $^{62}$, Paraguai ${ }^{63}$, Venezuela ${ }^{64}$ e Panamá ${ }^{65}$. A República

\footnotetext{
${ }^{56}$ Tribuna Popular, 05 de abril de 1946.

${ }^{57}$ A Noite, 04 de abril de 1946, p. 12.

${ }^{58}$ A Noite, 09 de abril de 1946, p. 7. Ver também: FOREIGN RELATIONS, 1946, VOLUME XI. Disponível em: http://digicoll.library.wisc.edu/cgi-bin/FRUS/FRUS-idx?type=turn\&entity=FRUS.FRUS 1946v11.p0026\&id=FRUS.FRUS1946v11\&isize=text Acesso em: 08 de junho de 2015.

${ }^{59} \mathrm{Na}$ resposta do Embaixador do Equador, o mesmo expressou que a posição do País tinha também o apoio do Chile e do Peru: Disponível em: https://history.state.gov/historicaldocuments /frus1946v11/d197m Acesso em: 14/11/2015.

${ }^{60}$ Segundo a embaixada dos EUA no México, o governo mexicano pediu explicitamente que seu país não fosse numericamente incluído entre aqueles que concordavam com a avaliação dos EUA sobre a situação da Argentina: Disponível em: http://digicoll.library.wisc.edu/cgi-bin/FRUS/FRUS-idx?type=turn\&entity $=$ =FRUS.FRUS1946v11.p0037\&id=FRUS.FRUS1946v11\&isize=text Acesso em: 15/02/2016

${ }^{61}$ Disponível em: http://digicoll.library.wisc.edu/cgi-bin/FRUS/FRUS-idx?type=turn\&entity=FRUS.FR US1946v11.p0032\&id=FRUS.FRUS1946v11\&isize=text Acesso em: 02/02/2016.

${ }^{62}$ Disponível em: http://digicoll.library.wisc.edu/cgi-bin/FRUS/FRUS-idx?type=turn\&entity=FRUS.FRU S1946v11.p0033\&id=FRUS.FRUS1946v11\&isize=text Acesso em: 02/02/2016.
}

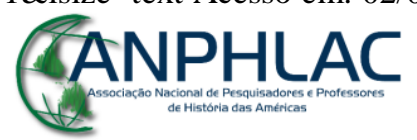

Revista Eletrônica da ANPHLAC, ISSN 1679-1061, №. 22, p. 231-257, Jan./Jun., 2017.

http://revista.anphlac.org.br 
Dominicana $^{66}$ e a Colômbia ${ }^{67}$ manifestaram posições bastante ambíguas. Assim, é possível perceber que a maioria dos governos que responderam à consulta dos EUA manifestou uma posição contrária à defendida pelo mesmo. ${ }^{68}$ Posicionamentos entusiasticamente favoráveis aos EUA vieram apenas do Uruguai, da Guatemala, da Nicarágua ${ }^{69}$ e de Honduras $^{70}$. As respostas parecem ter agradado mais ao governo da Argentina do que ao governo dos EUA.

A partir de Março de 1946, quando a vitória eleitoral de Perón se concretizou, a imprensa brasileira começou a repercutir declarações de autoridades dos EUA criticando a publicação do Livro Azul e a política de tipo intervencionista praticada pelo subsecretário Braden. Foi o caso, por exemplo, das declarações do Senador Republicano Harlan Bushfield, sendo que o Senador parece muito preocupado também em evitar que se cometesse contra a Espanha de Franco o mesmo "erro" que se cometeu contra a Argentina: "A despeito da experiência argentina, o departamento de Estado ainda insiste em envolver a ONU nas questões internas da Espanha."71 Também, a imprensa parece ter reavaliado sua posição depois da confirmação do resultado das eleições argentinas. O Correio da Manhã publicou um texto intitulado Inútil recordar os erros do passado: trigo não tem cor política; o primeiro título refere-se a um editorial do New York Times que defende a manutenção das relações com a Argentina e o reconhecimento da vitória de Perón; o segundo remete a uma matéria do La Guardia que ressaltava a dependência que o mundo do pós-guerra tinha do trigo argentino. ${ }^{72}$

Em meados de Abril, A Noite, usando como fonte a United Press, cita uma Conferência de Summer Welles com duras críticas à política recente dos EUA para a

\footnotetext{
${ }^{63}$ Disponível em: http://digicoll.library.wisc.edu/cgi-bin/FRUS/FRUS-idx?type=turn\&entity=FRUS.FRU S1946v11.p0036\&id=FRUS.FRUS1946v11\&isize=text Acesso em: 06/02/2016.

${ }^{64}$ Disponível em: http://digicoll.library.wisc.edu/cgi-bin/FRUS/FRUS-idx?type=turn\&entity=FRUS.FRU S1946v11.p0038\&id=FRUS.FRUS1946v11\&isize=text Acesso em: 10/02/2016.

${ }^{65}$ Disponível em: http://digicoll.library.wisc.edu/cgi-bin/FRUS/FRUS-idx?type=turn\&entity=FRUS.FRU S1946v11.p0030\&id=FRUS.FRUS1946v11\&isize=text Acesso em: 10/02/2016.

66 Disponível em: https://history.state.gov/historicaldocuments/frus1946v11/d184 Acesso em: 08/03/2016.

67 Disponível em: https://history.state.gov/historicaldocuments/frus1946v11/d191 Acesso em: 08/03/2016.

${ }^{68}$ Disponível em: http://digicoll.library.wisc.edu/cgi-bin/FRUS/FRUS-idx?type=turn\&entity=FRUS.FR US1946v11.p0221\&id=FRUS.FRUS1946v11\&isize=text Acesso em: 08/03/2016.

${ }^{69}$ Disponível em: http://digicoll.library.wisc.edu/cgi-bin/FRUS/FRUS-idx?type=turn\&entity=FRUS.FRU S1946v11.p0245\&id=FRUS.FRUS1946v11\&isize=M Acesso em: 08/03/2016.

${ }^{70}$ Disponível em: http://digicoll.library.wisc.edu/cgi-bin/FRUS/FRUS-idx?type=turn\&entity=FRUS.FRU S1946v11.p0246\&id=FRUS.FRUS1946v11\&isize=M Acesso em: 15/03/2016.

${ }^{71}$ Correio da Manhã, 20 de março de 1946, capa.

${ }^{72}$ Correio da Manhã, 31 de março de 1946.
}

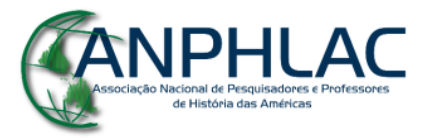


América Latina, e especialmente à política "unilateral e coercitiva contra a Argentina". O ex-Subsecretário de Estado solicitou o retorno imediato da política de boa vizinhança e citou explicitamente o Livro Azul, acusando o departamento de Estado de "opor-se em forma histérica à eleição de Perón". Também reclamou dos dois adiamentos da Conferência do Rio de Janeiro e solicitou imediata reunião de todos os chanceleres do Continente para "que possa ser reparado, antes que seja demasiado tarde, o dano à solidariedade do hemisfério." ${ }^{, 73} \mathrm{O}$ resultado das eleições na Argentina e as respostas dos países latino-americanos ao memorando que acompanhou o Livro Azul parecem ter mudado bastante o clima em torno do problema argentino, inclusive com repercussões internas nos EUA.

É claro que o Brasil, por ser a sede da próxima conferência continental e principal aliado dos EUA durante a Segunda Guerra, teve um papel central nos rumos que o problema Argentino tomou. Cabia ao Brasil convidar as representações das Repúblicas americanas. Pela documentação do Itamaraty, reunida na pasta sobre a Conferência do Rio de Janeiro, podemos perceber que o governo brasileiro buscou se informar sobre a posição das Repúblicas do continente em paralelo às informações que recebia dos EUA. Como exemplo, podemos citar que a Embaixada do Brasil no Peru enviou para o Itamaraty um recorte do Jornal La Cronica com a divulgação da resposta do governo peruano ao Livro Azul. Resposta em grande parte semelhante à do Brasil, ressaltando que as eleições na Argentina mudaram o cenário e que o país deveria participar da Conferência do Rio de Janeiro. ${ }^{74}$ Também encontramos uma resposta oficial do Ministério das Relações Exteriores da Venezuela enviada diretamente para o Itamaraty, igualmente concordando que a Argentina deveria participar da Conferência do Rio de Janeiro, uma vez que as eleições reestabeleceram as condições democráticas no país. ${ }^{75}$ Devemos notar que quando o Departamento de Estado dos EUA comunicou a resposta dos países latino-americanos, listou dez repúblicas, mas não incluiu a Venezuela e o Panamá. Temos evidências para acreditar que o governo dos EUA tentou minimizar o número de respostas negativas ao seu interesse no seu comunicado ao público.

\footnotetext{
${ }^{73}$ A Noite, 15 de abril de 1946, p. 10.

${ }^{74}$ Oficio 6870, de 07 de maio de 1946. Lata 1797 AHI.

${ }^{75}$ Estados Unidos da Venezuela, ofício 1129. Lata 1797, AHI.
}

\section{GANPHLAC}


Talvez o documento mais importante encontrado no arquivo do Itamaraty tenha vindo da Embaixada dos EUA no Brasil. No início de Abril de 1946, a Embaixada dos EUA informou ao Itamaraty o conteúdo das respostas dos países americanos ao Livro Azul nos mesmos termos vagos que foram noticiados pela imprensa, mas, na nota oficial, o governo dos EUA admite que diante do conteúdo das respostas passava a defender que a Conferência do Rio de Janeiro ocorresse o mais rápido possível ${ }^{76}$ e com a participação de todas as Repúblicas, algo que não foi publicizado de forma explícita naquele momento. Posteriormente, a União Pan-americana decidiu que caberia ao governo do Brasil marcar a data mais apropriada e formalizar os convites, embora, evidentemente, tudo continuasse a ser coordenado com o governo dos EUA.

A Conferência do Rio de Janeiro, que na realidade ocorreu no Hotel Quitandinha em Petrópolis, foi marcada para Agosto de 1947 e a Argentina participou de forma destacada. A nação platina chegou a pleitear junto às outras Repúblicas do continente a vice-presidência da Reunião ${ }^{77}$, pleito que foi prontamente recusado. A Delegação do Uruguai na União Pan-americana, antes da realização da Conferência, ainda apresentou uma proposta de Tratado de Mútua Defesa inspirado na Doutrina Larreta, que parece ter recebido o apoio da Guatemala. ${ }^{78}$ A proposta foi derrotada. Contudo, neste texto, não entraremos em detalhes sobre a Conferência em si. Nosso objetivo principal foi mostrar as dificuldades que envolveram a montagem do sistema interamericano entre a Conferência de Chapultepec e a Conferência do Rio de Janeiro, a centralidade do problema Argentino e o comportamento dos EUA e do Brasil em relação ao mesmo, bem como as repercussões da questão na imprensa brasileira.

Antes da realização da Conferência do Rio de Janeiro ainda houve tempo para que o chanceler brasileiro João Neves da Fontoura fosse substituído por Raul Fernandes, jurista e diplomata ligado à União Democrática Nacional (UDN), em função do acordo interpartidário celebrado entre o Partido da Social Democracia (PSD), do presidente Dutra, e a UDN. Porém, ainda que Raul Fernandes seja reconhecido como um chanceler profundamente submisso aos interesses dos EUA, essa mudança não

\footnotetext{
${ }^{76}$ Memorando 5007 de 05 de abril de 1946. Lata 1797, AHI.

${ }^{77}$ Embaixada do Brasil na Argentina, embaixador, Oswaldo Furst, 02/02/1974. Ofício 7286. Lata 1845. AHI.

${ }^{78}$ Embaixada do Brasil no Uruguai, enviado pelo Embaixador José Roberto de Macedo Soares, em 11 de maio de 1946, ofício 7752, Lata 1797, AHI.
}

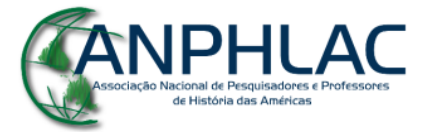

Revista Eletrônica da ANPHLAC, ISSN 1679-1061, №. 22, p. 231-257, Jan./Jun., 2017.

http://revista.anphlac.org.br 
parece ter influenciado seriamente a realização e os desdobramentos da Conferência do Rio de Janeiro nem o posicionamento do Brasil frente ao problema argentino.

\section{Conclusão}

Os Estudos sobre as relações internacionais do Brasil no imediato pós-guerra destacam o alinhamento automático do Brasil com as posições dos EUA. Gerson Moura chamou a política externa do Governo Dutra, tendo a frente, na maior parte do tempo, os Diplomatas João Neves da Fontoura e Raul Fernandes, de "alinhamento sem recompensas." (MOURA, 1991) ${ }^{79}$ Paulo Visentini vai mais longe e afirma que a diplomacia no governo Dutra vinculou-se "estreitamente à estratégia da Casa Branca", e que, especialmente Raul Fernandes, teve uma atuação "subserviente" e "quase caricatural." (VISENTINI, 2003, p. 23) ${ }^{80}$ Tratando mais especificamente das relações do Brasil com a Argentina, Amado Cervo chamou a mesma de "diplomacia da obstrução." (CERVO, 2001, p. 157) ${ }^{81}$ Também essa é a opinião de Iuri Cavlak que fez um estudo bastante completo sobre as relações diplomáticas dos dois países durante o governo de Perón. (CAVLAK, 2008, p. 57) ${ }^{82}$ De modo geral, concordamos com todos esses vaticínios, porém, a reação do Brasil à divulgação do Livro Azul pode indicar os limites do "alinhamento sem recompensas".

No final, a consequência mais imediata da divulgação do Livro Azul no Brasil foi a cassação do agrément do Embaixador Eduardo Aunós, que já havia sido indicado pela Espanha para assumir seu posto no Brasil. Em estudo específico sobre o caso, Sandra Brancato conclui que a cassação do agrément e a declaração de Aunós como persona non grata pelo governo Dutra poucos dias depois da divulgação do Livro Azul justifica-se pela necessidade que o governo brasileiro tinha em reafirmar seu compromisso com a democracia, sua aliança preferencial com os EUA e seu distanciamento do fascismo. (BRANCATO, 2007, p. 152) ${ }^{83}$ O problema é que os mesmos motivos teriam que levar a um posicionamento mais duro com relação à Argentina de Perón, mas isso não ocorreu.

\section{CANPHLAC}

Revista Eletrônica da ANPHLAC, ISSN 1679-1061, №. 22, p. 231-257, Jan./Jun., 2017.

http://revista.anphlac.org.br 
No continente, talvez, a consequência mais direta do Livro Azul tenha sido o Golpe que derrubou Villarroel na Bolívia. Pelo menos, é nisso que acredita Laurence Whitehead. (1996, p. 203) ${ }^{84}$ Mas, ao menos outro especialista considera que não se pode fazer uma ligação direta entre as ações do Secretário Braden, a divulgação do Livro Azul e a queda de Villaroel. (ZANATTA, 2006) ${ }^{85}$ Vimos que o Departamento de Estado dos EUA não se sentiu confortável diante das respostas dos países do continente em relação à sua política de exclusão da Argentina. Sabemos que mais de dez países responderam à consulta, e dentre eles uma parte razoável considerou que as denúncias estavam ultrapassadas, incluindo o Brasil e o México. A maioria dos países do continente defendeu que a Argentina deveria participar da Conferência do Rio de Janeiro com todos os seus direitos.

Voltando ao Brasil, uma entrevista que Dutra concedeu ao New York Tribune Herald no auge da crise, e que o Itamaraty arquivou, talvez possa esclarecer a posição do país. Afirmou o presidente que a URSS era o "maior perigo que ameaça o mundo", e, portanto, as nações americanas, "inclusive os Estados Unidos da América", devem chegar a "um acordo com a Argentina, qualquer que seja o perigo que possa representar o presidente eleito, Coronel Juan Domingo Perón, com o fim de construir uma frente única contra os Soviets." ${ }^{86}$ O Brasil não estava disposto a ter um inimigo nas suas fronteiras e defendia que o isolamento da Argentina poderia jogar o país platino na alçada de influência soviética, percepção que só foi agravada com o reatamento das relações entre a Argentina e a URSS. Por maiores que fossem as restrições do governo Dutra ao governo de Perón, maior era o temor de enfrentar diretamente a Argentina, considerada naquela época uma nação mais desenvolvida econômica e militarmente que o Brasil. Obstruir sim, enfrentar não, parece ter sido o lema do governo brasileiro para a Argentina, ainda que isso pudesse desagradar aos EUA.

\section{Fontes Primárias}

Arquivo do Itamaraty

${ }^{86}$ Ofício 306, de 14 de março de 1946 apud CAVLAK, Iuri, 2008, p. 90.

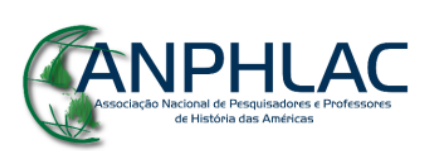

Revista Eletrônica da ANPHLAC, ISSN 1679-1061, №. 22, p. 231-257, Jan./Jun., 2017.

http://revista.anphlac.org.br 
Latas: 88, 1797, 1847, 1879, 1983.

CPDOC: Arquivos Oswaldo Aranha, Getúlio Vargas e Eurico Gaspar Dutra.

Biblioteca Nacional:

Correio da Manhã e A Noite, Jornal do Comércio e Jornal do Brasil, consultadas edições entre Abril de 1945 e Outubro de 1947.

Arquivo Digital da Revista “The Nation”.

\section{Referências Bibliográficas}

BANDEIRA, Luiz Alberto Moniz. Brasil, Argentina e Estados Unidos: conflito e integração na América do Sul. Rio de Janeiro: Civ. Brasileira, 2010.

BLUE BOOK ON ARGENTINA. consultation among the American republics with respect to the Argentine situation: memorandum of the United States government, Washington, D. C., February 1946.

BRANCATO, Sandra M. L. O Caso Aunós na versão da grande imprensa carioca e do Itamaraty. Estudos Ibero-Americanos, PUCRS, v. XXXIII, n. 2, dezembro 2007, p. 152. CALIL, Gilberto Grassi. O Integralismo no processo político brasileiro: O PRP entre 1945 e 1965: Cães de Guarda da Ordem Burguesa. Tese de Doutorado, Niterói: Universidade Federal Fluminense, 2005.

CASTRO, Fernando L. V. O pan-americanismo em jogo. Revista de História da Biblioteca Nacional. Rio de Janeiro, p. 18-21, jul. 2007.

CAVLAK, Iuri. A Política externa brasileira e a argentina peronista (1946-1955). São Paulo: Anablume, 2008.

CERCO, Amado Luiz. Relações Internacionais da América Latina: Velhos e Novos Paradigmas. Brasília: IBRI, 2001.

DUROSELlE, Jean-Baptiste. Todo Império Perecerá. Brasília/São Paulo: Ed. UNB. 2000.

GARCIA, Eugênio V. De como o Brasil quase se tornou membro permanente do Conselho de Segurança da ONU em 1945. Rev. bras. polít. int. [online]. 2011, vol. 54, n. 1.

GONÇALVES, Luiz Eduardo Fonseca de Carvalho. As relações Brasil-CEPAL. Brasília: Fundação Alexandre de Gusmão, 2011.

\section{CANPHLAC}

Revista Eletrônica da ANPHLAC, ISSN 1679-1061, №. 22, p. 231-257, Jan./Jun., 2017.

http://revista.anphlac.org.br 
GOÑI, Uki. A verdadeira Odessa. Rio de Janeiro: Record, 2004.

LANGLEY, Lester. America and the Americas: The United States in the Western Hemisphere. Georgia: University of Georgia Press, 1989.

LANÚS, Juan Archibaldo. De Chapultepec al Beagle: política exterior argentina 19451980. Buenos Aires: Emecé, 1984.

MACDONALD, C. A. The Politics of Intervention: The United States and Argentina, 1941-1946. Journal of Latin American Studies, 12, Part 2, Nov. 1980.

MOURA, Gerson. Sucessos e Ilusões: relações internacionais do Brasil durante e após a Segunda Guerra Mundial. Rio de Janeiro: FGV, 1991.

NEWTON, Ronald C. The "Nazi menace" in Argentina, 1931-1947. Stanford, Calif.: Stanford University Press, 1992.

PERÓN, J. D. Libro Azul y Blanco. Buenos Aires: Prensa Argentina, 1946.

RAPOPORT, Mario. Argentina. In.: BETHELL, Leslie; ROXBOROUGH, Ian. A América Latina entre a Segunda Guerra Mundial e a Guerra Fria. Rio de Janeiro: Paz e Terra, 1996.

SALAZAR, Sergio M. La Democracia y el Sistema Interamericano: de la OEA a la Carta Democrática Interamericana. Agenda Internacional. Año VII, n. 16, 2002.

TOTTA, Antônio Pedro. O Amigo Americano: Nelson Rockefeller e o Brasil. São Paulo, Cia. das Letras, 2014.

TRASK, Roger R. The Impact of the Cold War on U.S.-Latin American Relations, 1945-1949. In: LAROSA, Michael; MORA, Frank O. Neighborly Adversaries: Readings in U.S.-Latin American Relations. Baltimore: The Johns Hopkins Press, 1996. TRINDADE, Hélgio. Integralismo: o fascismo brasileiro na década de 30, 2. Ed. São Paulo: DIFEL, 1979.

VISENTINI, Paulo F. A projeção internacional do Brasil, 1930-2012. Rio de Janeiro: Campus, 2013.

WHITEHEAD, Laurence. Bolívia. In: BETHELL, Leslie; ROXBOROUGH, Ian. A América Latina entre a Segunda Guerra Mundial e a Guerra Fria. Rio de Janeiro: Paz e Terra, 1996.

ZANATTA, Loris. The rise and fall of the third position: Bolivia, Perón and the Cold War, 1943-1954. Desarrollo Económico (B. Aires) [online], vol. 1, Selected edition, 2006.

\section{CANPHLAC}

Revista Eletrônica da ANPHLAC, ISSN 1679-1061, №. 22, p. 231-257, Jan./Jun., 2017.

http://revista.anphlac.org.br 